\title{
An Empirical Analysis of M \& A Performance of Chinese Listed Companies
}

\author{
Chongqian LI \\ School of Management \\ Wuhan University of Technology \\ Wuhan, china \\ e-mail: anna_great@sina.com
}

\author{
Mengnong ZHOU \\ School of management \\ Wuhan University of technology \\ Wuhan, china \\ e-mail: zhounm2006@sina.com
}

\begin{abstract}
This paper chooses the listed companies of $M \& A$ events in Shanghai and Shenzhen stock markets in 2012 as research samples, using factor analysis to analyze the performance of the two years before the $M \& A$ and the three years after the $M \& A$. The results show that: $M \& A$ shortterm is effective, long-term is invalid. In addition, using the multiple regression model to analyze the influence factors of $M$ \& A performance of listed companies, the empirical results show that the related party transactions have no significant impact on the performance of $M \& A$, the cash payment as a way of payment to improve corporate performance in the short term.
\end{abstract}

Keywords-M\&A; factor analysis; long-term performance

\section{INTRODUCTION}

Enterprise growth can be achieved through internal accumulation and $\mathrm{M} \& \mathrm{~A}$, compared to internal accumulation, $M \&$ A can

achieve faster capital concentration, economies of scale, cross-sectoral business and industrial chain expansion. Whether the $\mathrm{M}$ \& $\mathrm{A}$ behavior of listed companies will increase shareholders' wealth has received wide attention from all sectors of society.

The study by Eckbo and Thorburn (2010) shows that the ratio of target firm to acquisition firm has a significant effect on the excess returns of the acquirer, Rau and Vermaelen (2012) found that the merger did not receive excess returns. [1] Muller (2010) and Raven use the comparison of operating results to show that the earnings of the company after M \& A decline year after year. [2] there are differences in the findings of domestic $M$ \& A performance, Wang Songtao and Wen Xianyuan argue that different research conclusions are mainly due to different research methods. [3] Zhang xin research that after the acquisition, target corporate profitability has improved, While mergers and acquisitions have declined. [4] Tang Jianxin and He Hong studied the M \& A events of listed companies from 2008 to 2010, found that there were positive synergies in the short term and negative synergies in the long run. [5] Zhang Yi and Qiao Yuanbo found that mergers and acquisitions of listed companies is inefficient and did not achieve the integration of both resources and value creation. [6]

The current scholars' research on M \& A performance is mainly focused on the one year after $M \& A$ and less on the performance of $\mathrm{M} \& \mathrm{~A}$ in the three years after $\mathrm{M} \& \mathrm{~A}$. In order to better detect the factors of $M \& A$, This paper selects $36 \mathrm{M} \& \mathrm{~A}$ events in 2012 as a sample to study the M \& A performance of listed companies, study the performance changes of $\mathrm{M} \& \mathrm{~A}$ two years ago and three years later, validate the hypothesis by regression analysis, And draws the influence of each factor on the long-term and short-term performance of $\mathrm{M} \& \mathrm{~A}$ performance of Chinese listed companies.

\section{M \& A PERFORMANCE EVALUTION}

\section{A. Selecting Sample}

Studying the M \& A performance of listed companies by comparing the performance change of listed companies, the paper selects $36 \mathrm{M} \& \mathrm{~A}$ events of listed companies in China in 2012 as a sample. Screening criteria: (1) Selecting the M\&A events that M\&A companies accounted for more than $30 \%$ stake after the merger; (2) excluding ST companies, to avoid the special type of financial data of ST company interference analysis results; (3) excluding the acquisition of the remaining shares of the holding company by the M \& A company, because the business activities of the target enterprise have been significantly influenced by the $\mathrm{M} \& \mathrm{~A}$ company before the M \& A, and included in the consolidated statement; (4) Due to the special nature of the industry indicators, excluding mergers and acquisitions enterprises belong to the financial and integrated industry; (5) In order to avoid the impact of multiple acquisitions on corporate performance, excluding the acquisition of two years before and after three years occurred in other mergers and acquisitions of the company; (6) excluding B shares, $\mathrm{H}$ shares, because this paper focuses on the performance of Ashare listed companies. The data of this paper are from: CSMAR M \& A Research Database of Chinese Listed Companies, M \& A Disclosure Report, 2012 M \& A Financial Report Data and Juchao Website.

Payment means the payment method used by the buyer to obtain the seller's assets: Q1602 = Cash payment, Q1603 = Stock payment, Q1607 = Mixed payment of cash and stock items. 
TABLE I. TYPES OF MERGERS AND ACQUISITIONS AND INDUSTRY DISTRIBUTION

\begin{tabular}{|c|c|c|c|c|c|}
\hline number & Security Code & payment method & number & Security Code & payment method \\
\hline 1 & 000100 & Q1602 & 19 & 600649 & Q1602 \\
\hline 2 & 600132 & Q1602 & 20 & 600754 & Q1602 \\
\hline 3 & 000712 & Q1602 & 21 & 000698 & Q1603 \\
\hline 4 & 600823 & Q1602 & 22 & 002269 & Q1602 \\
\hline 5 & 000616 & Q1602 & 23 & 002114 & Q1603 \\
\hline 6 & 600458 & Q1602 & 24 & 600988 & Q1602 \\
\hline 7 & 600030 & Q1602 & 25 & 000938 & Q1603 \\
\hline 8 & 601600 & Q1602 & 26 & 002577 & Q1602 \\
\hline 9 & 000718 & Q1602 & 27 & 000999 & Q1602 \\
\hline 10 & 000918 & Q1602 & 28 & 002065 & Q1607 \\
\hline 11 & 600466 & Q1602 & 29 & 000547 & Q1607 \\
\hline 12 & 600325 & Q1602 & 30 & 600596 & Q1602 \\
\hline 13 & 600208 & Q1602 & 31 & 600141 & Q1602 \\
\hline 14 & 000553 & Q1602 & 32 & 600398 & Q1602 \\
\hline 15 & 002146 & Q1602 & 33 & 600594 & Q1602 \\
\hline 16 & 600970 & Q1602 & 34 & 600340 & Q1602 \\
\hline 17 & 002305 & Q1602 & 35 & 002567 & Q1602 \\
\hline 18 & 601958 & Q1602 & 36 & 002230 & Q1602 \\
\hline
\end{tabular}

\section{B. Selecting the Financial Indicators}

The purpose of $\mathrm{M} \& \mathrm{~A}$ of listed companies is mainly reflected in the aspects of improving profitability and development ability, enhancing debt repayment ability, improving capital operation efficiency and value creation ability. Li Shanming, Xu Guoxiang evaluate on M \& A Performance from five aspects: Capital Structure, Solvency, Profitability, Development Capability and Asset Management Capability, [7] Zhang Yi and Qiao Yuanbo studied from the first four aspects. Taking into account the disclosure of listed companies may be unrealistic data, so increase the value of the creation of indicators EVA, Because of the scale difference of listed companies, in order to unify the scale, we adopt EVA per share and total assets EVA relative index to express the value of listed companies. Select the listed companies $M$ \& A performance evaluation indicators in table 1.

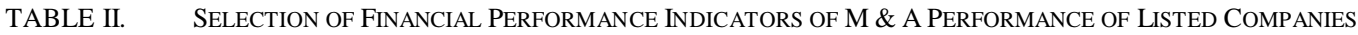

\begin{tabular}{|c|c|c|c|}
\hline Indicator type & Index selection & Indicator type & Index selection \\
\hline \multirow[t]{4}{*}{ Solvency } & Current ratio & \multirow[t]{2}{*}{ Operating capacity } & Receivable turnover ratio \\
\hline & $\begin{array}{l}\text { Tangible asset - liability } \\
\text { ratio }\end{array}$ & & Inventory turnover \\
\hline & Equity - to - liability ratio & \multirow[t]{3}{*}{$\begin{array}{l}\text { Value - added ability of } \\
\text { shareholders' equity }\end{array}$} & $\begin{array}{c}\text { Comprehensive income per } \\
\text { share }\end{array}$ \\
\hline & $\begin{array}{l}\text { Net cash flows / liabilities } \\
\text { arising from operating } \\
\text { activities }\end{array}$ & & $\begin{array}{l}\text { Earnings per share before } \\
\text { interest and tax }\end{array}$ \\
\hline \multirow[t]{4}{*}{ Development capacity } & Capital accumulation rate & & Net assets per share \\
\hline & Total Assets Growth Rate & \multirow[t]{2}{*}{ Corporation value } & EVA per share \\
\hline & $\begin{array}{c}\text { Rate of return on net } \\
\text { assets }\end{array}$ & & Total assets EVA rate \\
\hline & Sustainable growth rate & & \\
\hline
\end{tabular}




\section{Performance Evaluation Process and Results}

TABLE III. KMO TEST AND BARTLETT TEST

\begin{tabular}{|l|c|r|}
\hline \multicolumn{2}{|c|}{ Kaiser-Meyer-Olkin measures sampling appropriateness. } & 0.740 \\
\hline \multirow{2}{*}{ Bartlett test } & chi-square & 433.038 \\
\cline { 2 - 3 } & df & 105 \\
\cline { 2 - 3 } & Significance & 0.000 \\
\hline
\end{tabular}

According to using spss 22.0 analysis software test result: the $\mathrm{KMO}$ value is 0.74 , which is suitable for factor analysis. In order to facilitate the comparison of the performance of listed companies before $\mathrm{M} \& \mathrm{~A}$ and after $\mathrm{M} \& \mathrm{~A}$, this paper constructs comprehensive score function by using the main factors. The comprehensive score function is the sum of variance contribution of the factor using the sum of the product of the weight and the factor score. The results show that the comprehensive performance scores in one year after M \& A are significantly improved, but the performance score in three years after $\mathrm{M} \& \mathrm{~A}$ declines, indicating that $\mathrm{M}$ \& A effect of listed companies in the short term But the long-term effect is not obvious and there is a downward trend.

\section{AN EMPIRICAL ANALYSIS OF M \& A PERFORMANCE}

\section{A. Theoretical Analysis and Research Hypothesis}

The term "related party" means that in a business operation and financial decision, if one party can directly or indirectly control another party or exert a significant influence on the other party, the criterion regards it as a related party. "The reorganization of assets between affiliated enterprises can rapidly improve the operating results and financial position of listed companies. Xi Xin study shows that the performance of related party transactions and acquisition are related, [8] Hence the hypothesis:

H1: There is a positive correlation between related party transactions and $\mathrm{M} \&$ A performance.

At present, the main means of $\mathrm{M} \& \mathrm{~A}$ are asset payment, cash payment, stock payment, bond payment, debt, cash and Mixed payment of asset items, mixed payment of cash and stock items, mixed payment of cash items and commitment of debts, and other payment methods. Free cash flow theory from the perspective of the possibility of $M \& A$ explain the relationship between payment and M \& A performance that cash payment is superior to other payment methods in the short term to improve the performance of mergers and acquisitions have a certain role. Ge jiegeng study that: cash payments, cash and asset payment portfolio performance have no significant impact on $\mathrm{M}$ \& $\mathrm{A}$ performance improvement [9] Zhou Shaoni and Wang Huitong study that the stock payment method to improve the performance of $\mathrm{M}$ \& A to be significantly better than cash payments. [10] Hence the hypothesis:

H2: Cash payments have no significant impact on M \& A performance improvement.

TABLE IV. DEFINITION OF VARIABLES

\begin{tabular}{|c|c|c|c|}
\hline The type of the variable & \multicolumn{2}{|l|}{ Variable name } & $\begin{array}{c}\text { Variable description } \\
\end{array}$ \\
\hline \multirow[t]{6}{*}{ Dependent variable } & $\begin{array}{l}\text { M \& A performance of the first } \\
\text { two years before the average }\end{array}$ & Y-1 & $\begin{array}{l}\text { The arithmetic average of the two years' performance of } \\
\text { the acquired company acquired by the factor analysis } \\
\text { method }\end{array}$ \\
\hline & $\begin{array}{l}\mathrm{M} \& \mathrm{~A} \text { and } \mathrm{M} \& \mathrm{~A} \text { after the first } \\
\text { year performance average }\end{array}$ & Y0 & $\begin{array}{l}\text { Factor analysis of the acquisition of the acquisition of } \\
\text { mergers and acquisitions and } \mathrm{M} \& \mathrm{~A} \text { year after the first } \\
\text { year performance average }\end{array}$ \\
\hline & $\begin{array}{l}\text { M \& A performance of the } \\
\text { second and third year after the } \\
\text { average }\end{array}$ & Y1 & $\begin{array}{l}\text { Factor analysis method to obtain the acquisition of the } \\
\text { second and third year after the merger performance } \\
\text { average }\end{array}$ \\
\hline & Short-term performance changes & Ys & $\begin{array}{l}\text { Y0-Y-1, the average performance of the acquisition in } \\
\text { the first year after M \& A is compared with the average } \\
\text { of the two years before } \mathrm{M} \& \mathrm{~A} \text {. }\end{array}$ \\
\hline & Interim performance changes & Ym & $\begin{array}{l}\text { Changes in the average of the performance averages of } \\
\text { the second and third years after } \mathrm{M} \& \mathrm{~A} \text { of the acquired } \\
\text { company compared to the two years before the merger: } \\
\text { Y1-Y-1, }\end{array}$ \\
\hline & Long-term performance change & $\mathrm{Yl}$ & $\begin{array}{l}\text { Y2-Y-1. The change of the average of the performance } \\
\text { of the fourth and fifth years after acquisition is relative } \\
\text { to the average of the two years before the merger. }\end{array}$ \\
\hline \multirow[t]{2}{*}{ Independent variable } & Related party transactions & $\operatorname{Re}$ & $\begin{array}{l}\text { Dummy variable, the related party transaction is } 1 \text {, and } \\
\text { the non-related party transaction is } 0\end{array}$ \\
\hline & payment method & Pay & $\begin{array}{l}\text { The dummy variable, the cash payment is } 1 \text {, and the } \\
\text { non-cash payment is } 0\end{array}$ \\
\hline
\end{tabular}




\section{B. Data Sources and Model Settings}

In this study, the $36 \mathrm{M} \& \mathrm{~A}$ events from Shanghai and Shenzhen stock markets in 2012 are still used as initial research samples. Data are derived from the CSMAR database and the juchao website. The corresponding variables are set based on the above assumptions. In order to analyze the influence factors of $\mathrm{M} \& \mathrm{~A}$ performance, this paper adopts the multiple linear regression method to test the effect of variables on $M \& A$ performance. The research model is:

$$
\mathrm{Yt}=\beta(0, \mathrm{t})+\operatorname{Re} \beta(2, \mathrm{t})+\mathrm{Pay} \beta(3, \mathrm{t})
$$

Where $\mathrm{Yt}$ is $\mathrm{Ys}, \mathrm{Ym}, \mathrm{Yl}$.

\section{Empirical Results and Analysis}

Table 3 shows the descriptive statistics of the sample data of $36 \mathrm{M} \&$ A companies in 2012. It can be seen from the table that there is an upward trend in the overall performance of the acquisition companies from short-term to long-term after acquisition (average value of $\mathrm{Ys}$ is $0.3326, \mathrm{Yl}$ is 0.743 ), indicating that mergers and acquisitions have good business results, resulting in synergies.

TABLE V. DESCRIPTIVE STATISTICAL TABLES OF ACQUIRED COMPANY DATA

\begin{tabular}{|l|c|c|c|c|c|}
\hline & $\mathrm{N}$ & Minimum & Maximum & average & $\begin{array}{c}\text { standard } \\
\text { deviation }\end{array}$ \\
\hline Ys & 32 & -1.2249 & 0.7629 & 0.3326 & 0.4061 \\
\hline Ym & 32 & -0.6024 & 0.5344 & 0.570 & 0.2593 \\
\hline Y1 & 32 & -0.7684 & 0.6131 & 0.7430 & 0.2932 \\
\hline $\operatorname{Re}$ & 32 & .0 & 1.0 & 0.156 & 0.3689 \\
\hline Pay & 32 & .0 & 1.0 & 0.844 & 0.3689 \\
\hline $\begin{array}{l}\text { EffectivN } \\
\text { (listwise) }\end{array}$ & 32 & & & & \\
\hline
\end{tabular}

TABLE VI. MULTIPLE LINEAR REGRESSION RESUlTS OF THE FACTORS AFFECTING M \& A PERFORMANCE

\begin{tabular}{|c|c|c|c|}
\hline & Ys & Ym & Yl \\
\hline _cons & $-0.113(0.227)$ & $0.176(0.334)$ & $0.158(0.367)$ \\
\hline Re & $0.081^{*}(0.099)$ & $-0.221(0.198)$ & $-0.015(0.177)$ \\
\hline Pay & $0.269 *(0.049)$ & $-0.105^{* *}$ & $-0.186(0.223)$ \\
& & $(0.037)$ & 0.54 \\
\hline $\mathrm{R}^{2}$ & 0.726 & 0.69 & 60.693 \\
\hline $\mathrm{F}$ & 72.33 & 67.33 & 2.13 \\
\hline DW & 1.431 & 1.76 & \\
\hline
\end{tabular}

According to the regression results in Table 4 , the $\mathrm{R}^{2}$ of $\mathrm{Yl}$ in the three regression equations is the lowest, which is 0.54 , meaning that $54 \%$ of the long-term $\mathrm{M} \& \mathrm{~A}$ performance of listed companies can be explained by the selected variables.

In the short term, The $\mathrm{M} \& \mathrm{~A}$ of cash transactions has a positive effect on short-term $M$ \& A performance, which is not consistent with the hypothesis 2 , that is cash payment transaction has significant effect on $\mathrm{M} \& \mathrm{~A}$.the influence of the relationship between $M \& A$ enterprises on the $M \& A$ performance of the $\mathrm{M} \& \mathrm{~A}$ results: at the significance level of 0.1 , rejecting the original hypothesis, that is the related party transaction and the $\mathrm{M} \& \mathrm{~A}$ performance is not a positive correlation.

In the medium term, Cash payment has significant effect on $M$ \& A performance, cash payment is opposite to the change of $M$ \& A performance, which is not consistent with the hypothesis 2, This situation may arise because the enterprise to obtain the target business assets and undertake a new debt, a large number of cash outflows in the early stages of mergers and acquisitions, the company's cash "hematopoietic" function is affected, and a large number of mid-term debt also affected the performance of the enterprise.

In the long run, related party transactions, payment methods on the long-term performance is not significant, indicating that China's listed companies mergers and acquisitions in the long term is inefficient.

\section{CONCLUSIONS}

Based on the study of the short-term performance (the first year after acquisition), the mid-term performance (the second year after acquisition) and the long-term performance (the third year after acquisition) of $36 \mathrm{M} \& \mathrm{~A}$ samples in 2012, It is found that the M \& A of the listed companies in our country has a positive effect on the operating performance in the short term, but the long-term impact on the performance is not optimistic. Cash payment can only improve $M$ \& A performance in the short term, and it is inefficient in the long run and the related party transaction and the $\mathrm{M} \& \mathrm{~A}$ performance is not a positive correlation after the acquisition.

\section{REFERENCES}

[1] H.Singh, Corporate acquisition strategies and economic performance, Strategic Management Journal,vol.8,2012,pp.377-387,2012.

[2] S.K.Muller, Measuring and managing the value of Companies, Strategic Management Journal,vol.12,pp.256-265,2010.

[3] Wang.Songtao, Wen. Xianyuan, On the effectiveness of the capital markets and $M$ \& A performance study methods: evidence from Chinese Listed Companies, Journal of Nanjing Audit University,vol.5,pp71-80,2012.

[4] Zhang.xin, Does merger and reorganization create value? Theoretical and Empirical Research on China's Securities Market, Economic Research Journal,vol.6,pp.23-28,2013.

[5] Zhang yi,Qiao yuanbo, Empirical and empirical analysis on M \& A performance of chinese listed companies, Research on Financial and Economic Issues,vol.1,pp.60-68,2015.

[6] Y. Yorozu, M. Hirano, K. Oka, and Y. Tagawa, "Electron spectroscopy studies on magneto-optical media and plastic substrate interface," IEEE Transl. J. Magn. Japan, vol. 2, pp. 740-741, August 1987 [Digests 9th Annual Conf. Magnetics Japan, p. 301, 1982].

[7] Li shanming, An empirical study on the performance of the pairing of acquired and target companies, Economic Research Journal,vol.9,pp.96-104, 2009.

[8] Xi xin, An Empirical Study on the Influencing Factors of M \& A Performance of Listed Companies, Industrial Technology \& Economy,vol.9,pp.140-146,2010.

[9] Ge jiegeng, An Empirical Study on M \& A Payment and M \& A Performance, Accounting Research,vol.9,pp.74-80,2015.

[10] Zhou shaoni,wang huitong, Payment Method, Corporate Governance and $\mathrm{M} \& \mathrm{~A}$ Performance, Journal of Beijing Jiaotong University(Social Sciences Edition),vol.2,pp.39-44,2014. 